\title{
Determination of Effective Mutagen Dose for Carrot (Daucus carota ssp. sativus var. atrorubens alef and $D$. carota) Callus Cultures
}

\author{
Damla Turan Buyukdinc (Corresponding author) \\ Recep Tayyip Erdogan University, Faculty of Agriculture and Natural Sciences, \\ Department of Horticulture, Pazar-Rize, Turkey \\ E-mail: damla.turan@erdogan.edu.tr \\ K. Yaprak Kantoglu \\ Turkish Atomic Energy Authority, Saraykoy Nuclear Research and Training Center, \\ Unit of Agriculture, Ankara, Turkey \\ E-mail: yaprak.taner@taek.gov.tr \\ Arzu Karatas \\ Recep Tayyip Erdogan University, Faculty of Agriculture and Natural Sciences, \\ Department of Horticulture, Pazar-Rize, Turkey \\ E-mail: arzu.karatas@erdogan.edu.tr \\ Ahmet Ipek \\ Uludag University, Faculty of Agriculture, \\ Department of Horticulture, Bursa, Turkey \\ E-mail: maipek@uludag.edu.tr \\ S. Sebnem Ellialtioglu \\ Ankara University, Faculty of Agriculture, \\ Department of Horticulture, Ankara, Turkey; \\ E-mail: ellialti@agri.ankara.edu.tr
}

\begin{abstract}
Mutation breeding is used for plant variety, to obtain high yield, earliness, resistance to pest and diseases and also to abiotic stress conditions. Gamma radiation application in physical mutagen applications has advantages on the ease of use, the high permeability and the ability to reach the target cells and the nontoxic and harmful effects. It expanses the present variation by creating a mutation with physical mutagenesis via $\mathrm{Co}^{60}$ irradiation applied to in vitro donor plant tissues, and provides selection of variations at the cellular level in desired properties. Carrot is an important vegetable crops and in demand by the local markets throughout the year. This study was carried out to obtain a database and to determine the Effective Mutagen Dose $\left(\mathrm{EMD}_{50}\right)$ in the course of mutation breeding studies on purple and orange carrots. For this aim, 0, 5, $10,20,30,40,50$ and 60 Gray (Gy) doses of $\mathrm{Co}^{60}$ (gamma-rays) were applied to carrots calli as a physical mutagen of 30 callus pieces (each $1 \mathrm{~g}$ ) per dose. 4-5 weeks after irradiation, shoot development of callus were determined and $\mathrm{EMD}_{50}$ calculated by linear regression analyses. As a result of the research, it was determined that 8,36 Gy was an effective mutation dose for purple carrot and 23,605 Gy for orange carrots due to the regression analyses.
\end{abstract}

Key Words: Carrots, mutation breeding, $\mathrm{Co}^{60}$, gamma ray, effective mutagen (EMD 50 ), in vitro

DOI: $10.7176 / \mathrm{JSTR} / 5-3-02$

\section{Introduction}

Nutrition wise, carrots are major parts of the diet as they provide the majority of vitamin A and fibres needed by humans. Thus, according to Simon (1997) and Horvitz et al (2004), they are one of the most widely grown vegetable crops on earth. Carrots are one of the most important vegetable crops globally, with China producing the largest area $(130,000 \mathrm{ha})$, followed by the United States $(78,000 \mathrm{ha})$, Russia 
(25,000 ha) and Brazil (22,250 ha $)^{6}$. Increasing the agricultural worth of carrots can be carried out by increasing the quality and amount of produce, which is seen as an advantage as they are very important for the health of humans. There are a great variety of carrots, including red carrots that contain lycopene, yellow carrots that contain xanthophyll, white carrots that have no pigments resulting in colours, and purple carrots containing anthocyanin. Even though these carrots are also given land for growth, the majority of land used for carrot production is dedicated to the orange carrots that contain carotenoid in their roots. This is because carotenoid is the building block of vitamin A. However, Harborne and Williams (2000) reported there has been a recent increase in the production of anthocyanin pigment containing vegetables which is a major characteristic of purple carrots, due to people becoming increasingly aware of these vegetables being essential for a healthy diet. The vegetables that contain the flavonoid anthocyanin, which is also water soluble, have a characteristic purple, red, or blue colour and can be easily recognised.

It was reported by Ross and Kasum, (2002) anthocyanins have a myriad of advantages health-wise including properties like protection against coronary heart-related ailments, additional diseases related to old age, infections, and various cancers. Montilla et al (2011) reported that, another characteristic is that with changing $\mathrm{pH}$, changes in anthocyanin colour, from red to purple, can be observed, resulting in the increase of this pigment being used in ready meals in the food industry due to their use as natural colorants in food. Anthocyanin pigments, that are a type of cyanidin glycoside, are found to be abundant in purple carrots and their storage roots can gather nearly the fresh weight of $17-18 \mathrm{mg} / 100 \mathrm{~g}$.

In 2017, Turkey had a carrot yield of approximately $569533 \mathrm{t}$ grown on 10850 ha of agricultural land, with the provinces of Konya (355 652 t), Hatay (60 $483 \mathrm{t}$ ), and Ankara (132 $880 \mathrm{t}$ ) leading this production as they make up $93 \%$ of all the carrots produced according to the Turkish Statistical Institute (TUIK). Additionally, most of these produced carrots were orange carrots. For the production of a traditional drink known as 'salgam', mostly produced in Turkey's Mediterranean region, purple carrots which are known for containing a large amount of anthocyanin have been used for centuries. However, the production of purple carrots is very limited in Turkey today for the purpose of producing salgam, even though its production has been increasing exponentially for the purpose of extracting anthocyanin to be used by the pigment industry. From all the purple carrots grown in Turkey, $90 \%$ of them are used for the pigment industry with the entire yields of the pigment being exported. While the production of purple carrots is mostly concentrated in the Konya and Hatay provinces, most of them is grown in the Eregli District of Konya, with $95 \%$ of purple carrot production originating from this area. While even today the growth of purple carrots occurs by using local open-pollinated cultivars of these carrots, $90 \%$ of orange carrot production in Turkey utilize cultivars that are hybrid. Farmers, by choosing carrots that have a profound purple colouring in their storage roots, locally known as "black carrots", have grown and maintained the previously mentioned cultivars of purple carrots that are open pollinated, or landraces. Conventional breeding has greatly contributed to the enhancement of carrot traits. However, mutation breeding can provide an important complementary technology to improve carrot quality and productivity. Developing plants that are genetically modified are very favoured today. However, studies that are nuclear-based are cheaper when compared to transgenic plant lines that also have resulted in a lot of controversy around the world.

Nuclear-based studies enable a shorter time for conclusive results to be seen and doesn't have the disadvantages to human health associated with genetically modified plants and their development. In research mostly carried out in the past 50 years, it can be observed that, particularly in plants that are self-fertilized, the technique utilizing mutation breeding allows a significantly higher benefit in developing characters that reported by Anonymous (2018), Sağel et al (2002) and Waycott et al (1995), governed by one gene and that show simple inheritance. Mutations have also been successfully induced in physiological traits, and comprise such features as early, perpetual and rich flowering, changes in photoperiodic reaction, tolerance against abiotic stress factors and increased disease resistance.

It was reported by Schum (2003) that gamma radiation application in physical mutagen applications; easy to use, highly permeable, accessible to target cells and lack of any toxic effects and harms. In practice, nowadays, most often use is made of sparsely ionizing radiation, to which category X-rays and gamma rays belong. Gamma rays and X-rays are electromagnetic radiations and have an energy level that is high enough, to ionize atoms in molecules with which they interact. Gamma rays have shorter wavelengths, but otherwise are identical with X-rays with respect to their physical properties.

Normally, in vivo mutagen treated plants are grown under field condition and population size is restricted due to limitation of land and funding. Population size is reduced due to some unavoidable environmental conditions. It is well established that the larger the population size, the greater the chance of getting mutations. As mentioned, chimerism is the major drawbacks of in vivo mutation following the mutagenic

16 | P a g e

www.iiste.org 
treatment of multicellular organisms. Therefore, concept of in vitro mutagenesis has opened new possibilities for inducing an increased number of mutants and solid mutants. The main advantage of this technique is to overcome chimera formation. Mutation induction and selection of desired traits in combination with in vitro techniques offer several advantages over conventional methods. Any explant or callus can be treated with mutagen/s and they can be allowed to regenerate through in vitro methods. In in vitro methods, according to Ahloowalia (1995), Maliga (1984) and Maluszynski et al (1995) cells can be uniformly treated with physical and chemical mutagens and can be grown in a uniform cultural environment. In vitro mutagenesis experiments can be conducted with large populations, within limited space and any time of the year. The chances of getting solid mutant/s are more in in vitro mutagenesis. The main advantage of this method is that it helps to avoid chimera formation in the M1V1.

Many mutations are used to induce gamma radiation and X-ray mutations in therapy trials. Dosage limits to be used in mutation treatment studies should be well defined. For this, Sağel et al (2002) reported the concept of "effective dose (ED50)" or "dose reducing dose by 50\%" has been introduced. This value is different for each plant species and an effective dose rate should be determined before commencing mutation breeding trials.

According to Ahloowalia and Maluszynski (2001) in the development of direct mutant varieties, the most common $(89 \%)$ used metroid is induction of radiation mutation. Gamma rays $(64 \%)$ are the most commonly used source of radiation in mutagen applications, followed by X-rays $(22 \%)$. The use of chemical mutagens in breeding studies is rather limited.

Mou (2011) reported that mutations play an important role in genetic variation and in the cultivation of plants. Many features such as stunting, early flowering, male infertility, chlorophyll deficiency are very beneficial in physiological and genetic studies, with natural and induced mutations. Mutants are also used to develop new types of lettuce, such as miniature and herbicide tolerant. Mutant analysis has a critical prescription for lettuce genomic studies, such as identification and cloning of disease-resistance genes. Mutagenesis can also provide the discovery of new gene alleles with genomic technology.

Ahloowalia (1998) reported that tissue culture allows for the handling of large populations for mutagenic treatment, selection, and cloning of selected variants. It also offers the possibility to rapidly execute the propagation cycles of subculture aimed to separate mutated from non-mutated sectors (dissolving a chimera to obtain homo-histonts).

Somaclonal variation has led to the selection of several variants with increased resistance to pests, diseases, and herbicides. Somaclonal variation frequency is determined by a number of factors, including genotype, explant source, duration of culture, and medium composition. Callus cultures provide significant advantages to reveal somaclonal variation in plant breeding studies. When mutagen treatments are integrated, tissue culture techniques can be used to increase the genetic variation to higher frequencies. Callus tissues may provide advantages for mutation applications in breeding studies of carrot to be performed in vitro. For this, optimizing the plant regeneration system from callus is the first step necessary. To obtain successful results, it is important to know the susceptibility of the selected variety to mutations and, by determining the "Effective Mutation Dose" (EMD 50$)$, to start the studies with the correct irradiation dose for the genotype to be studied. In the first phase of the work we have planned to create a new variation in the carrot calli with the method of mutation breeding; Effective Mutation Dose $\left(\mathrm{EMD}_{50}\right)$ was determined by determining the effects of different gamma ray doses applied to the carrot callus tissues.

\section{Materials and Methods}

Carrot is a plant species which has quite high ability of somatic embryogenesis. In this research aimed at establishing a basis for breeding purposes. Plantlets grown from genetically homogene seeds of Nantes (Daucus carota) and a local black carrot genotype (Daucus carota ssp. sativus var. atrorubens alef) which has grown in vitro were cultured in MS medium ${ }^{19}$ containing different doses of 2, 4-D on aseptic conditions. The formation of shoots was observed from callus tissues transplanted to 2,4-D and Kinetin combinations. The calli obtained from the selected medium and explant source were irradiated with a gamma irradiation device which is used in experimental irradiation with the Isotope brand, the Ob-Servo Sanguis Co-60 Research Irradiator model (dose rate: 360 Gy / h); at Nuclear Research and Training Center, Department of Technology (Figure 1.). For this aim, 0, 5, 10, 20, 30, 40, 50 and 60 Grays (Gy) doses of $\mathrm{Co}^{60}$ (gamma-rays) were applied to carrots calli as a physical mutagen of 30 callus pieces (each $1 \mathrm{~g}$ ) per dose (Figure 2.). 4-5 weeks after irradiation, shoot development of callus were determined and $\mathrm{EMD}_{50}$ calculated by linear regression analyses. For the study, regeneration ability of non-irradiated callus (control group) and the test group to which the specified beam dose is applied were compared. 


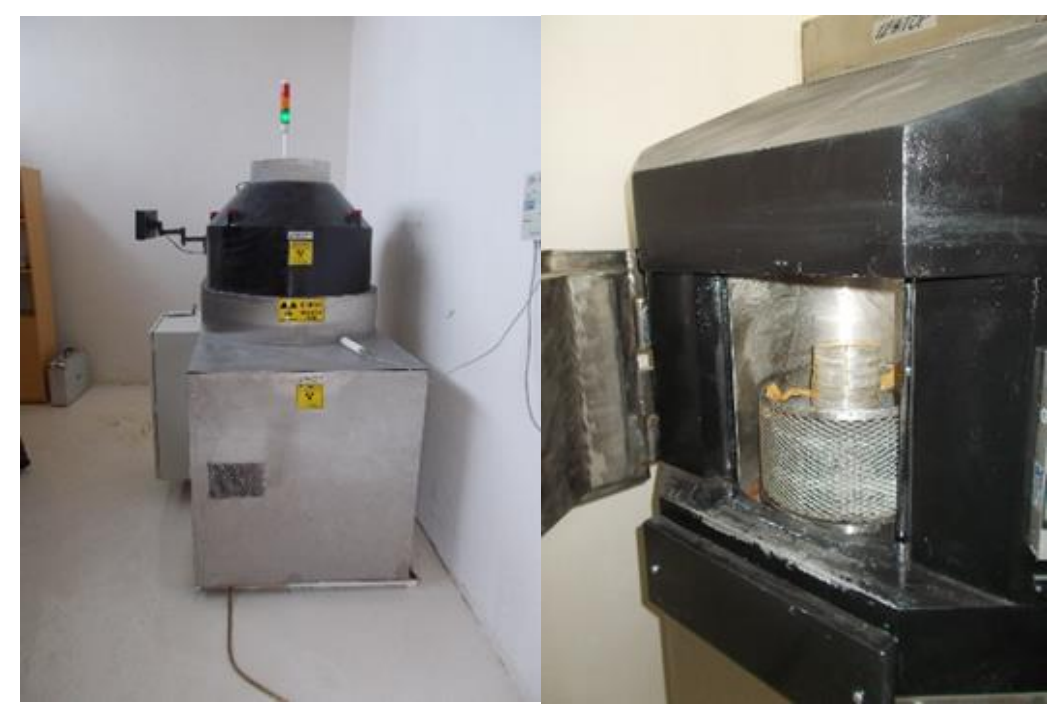

Figure 1. Ob-Servo Sanguis Co-60 Research Irradiator model (dose rate: 360 Gy / h)
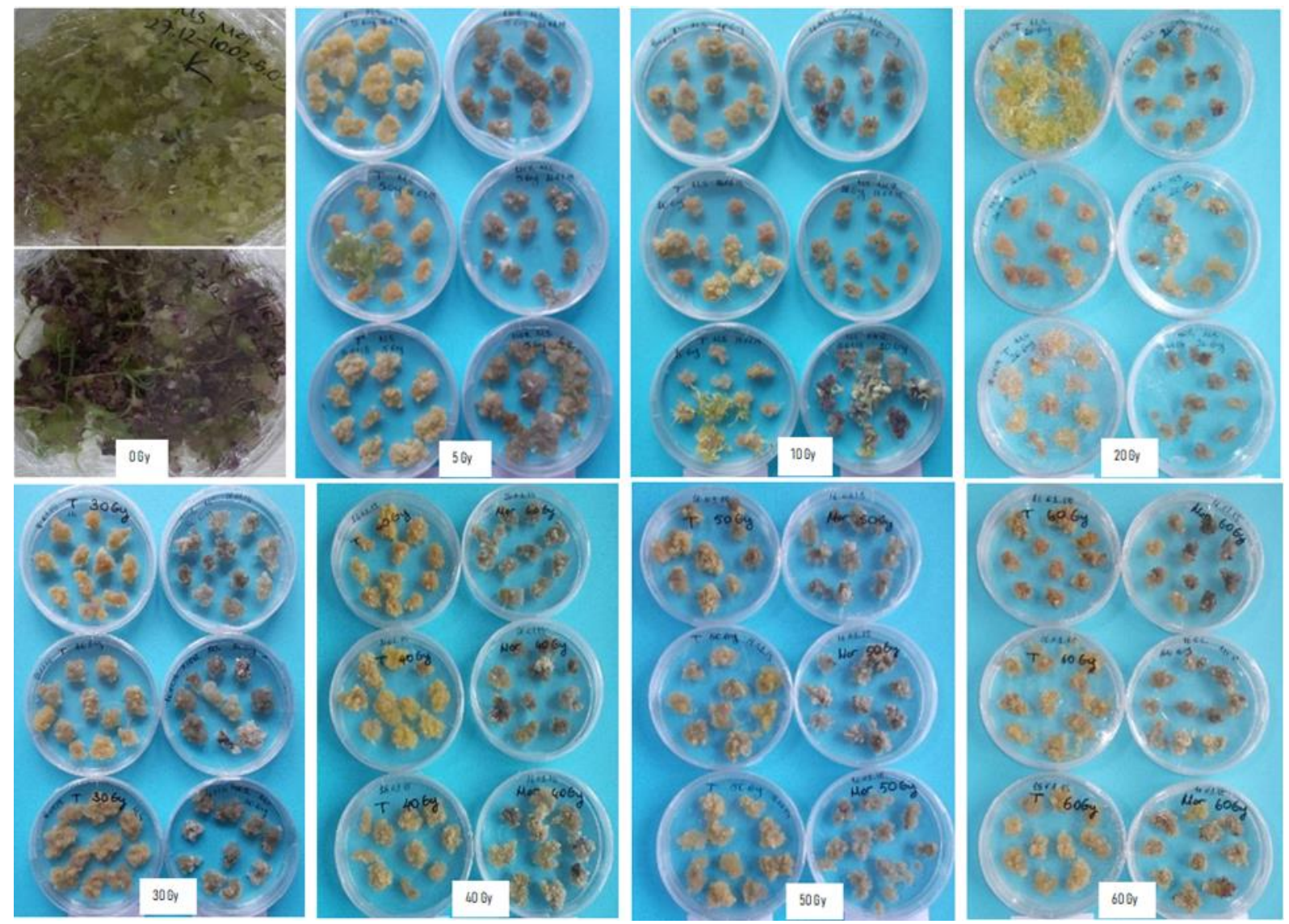

Figure 2. Regenerations from calli on different gamma-ray doses (Left column of petri dishes: Orange carrot variety; Right column of petri dishes: Purple carrot variety) 


\section{Results and Discussion}

After irradiation at 8 different doses with Co60 gamma ray source, all irradiated callus tissues subcultured to MS media ${ }^{19}$ which was without any plant hormones to obtain somatic embryos and plantlets. Each petri had 1 gram 10 pieces of callus and all the plantlets from the calli were counted. For the study, regeneration ability of non-irradiated callus (control group) and the test group to which the different gamma ray dose was applied were compared. As can be seen from Table 1 as a result of the counting's made on the $30^{\text {th }}$ day after irradiation, significant reductions in seedling numbers depending on the increasing irradiation dose was observed. As a result of the research, it was determined that 8,36 Gy was an effective mutation dose for purple carrot and 23,605 Gy for orange carrots due to the regression analyses made from the 7 different doses applied to the calli irradiated at this dose could form plants with a survival rate of 50\%. It was obtained 7, 524 Gy lower and 9, 196 Gy upper doses for purple carrots; 21,2445 Gy lower and 25,3605 Gy upper doses for orange carrots. After irradiation at 7 different doses with $\mathrm{Co}^{60}$ gamma ray source, plantlets regenerated from 30 calli of each dose were counted 30 days after irradiation and obtained the plantlet rates. It has shown the plant regenerations on callus tissues at Figure 3. For purple carrots control ( 0 dose) had 17,66 plantlets rate and 5 Gy dose had 2,67 plantlets rate, 10 Gy dose had 1,06 plantlets rate. The plantlet rate of $20 \mathrm{~Gy}$ dose, 1,80, is an expected effect of a low dose application which has been caused by the stimulating effect of germination or plant regeneration (Anonymous, 1977). The dose of 30 Gy or more there were no regeneration on the callus tissues of purple carrot genotype. For orange carrots control (0 Gy dose) had 6,87 Gy plantlets rate and 5 Gy dose had 4,70 Gy dose had plantlets rate, $10 \mathrm{~Gy}$ dose had 2,67 plantlets rate. If the results of orange carrots are to be examined, a case similar to that of the purple carrot genotype has emerged. The plantlet rate of $20 \mathrm{~Gy}$ dose had 10,1 plantlets rate which was more than control and the other plantlet rate, is an expected effect of a low dose application which has been caused by the stimulating effect of germination or plant regeneration. At the dose of $30 \mathrm{~Gy}$ or more doses there were no regeneration on the callus tissues of orange carrot species like purple carrot genotype. It was observed that for both carrot species the number of regenerated plantlets numbers have decreased due to the increased radiation dose (Figure 4).

Table 1. Values in the plants obtained from irradiated calli at different doses

\begin{tabular}{|c|c|c|}
\hline \multirow[t]{2}{*}{ Irradiation doses } & \multicolumn{2}{|c|}{ Number of plantlets rates } \\
\hline & Purple carrot & Orange carrot \\
\hline 0 (control) & 17,66 & 6,87 \\
\hline 5 & 2,67 & 4,70 \\
\hline 10 & 1,06 & 2,67 \\
\hline 20 & 1,80 & 10,1 \\
\hline 30 & 0 & 0 \\
\hline 40 & 0 & 0 \\
\hline 50 & 0 & 0 \\
\hline 60 & 0 & 0 \\
\hline $\begin{array}{l}\text { Regression Rate } \\
\text { According to Mean } \\
\text { plantlet number }\end{array}$ & $\begin{array}{l}\mathbf{x}=\mathbf{8 , 3 6} \mathbf{G y} \\
\text { Number of plantlets }= \\
(-0,1683 x)+7,4218 \text { dose, } \\
\left.\mathrm{R}^{2}=1\right)\end{array}$ & $\begin{array}{l}\mathbf{x}=\mathbf{2 3 , 6 0 5} \mathbf{G y} \\
(\text { Number of plantlets }= \\
(-0,1201 \mathrm{x})+6,27 \text { dose, } \\
\left.\mathrm{R}^{2}=1\right)\end{array}$ \\
\hline
\end{tabular}




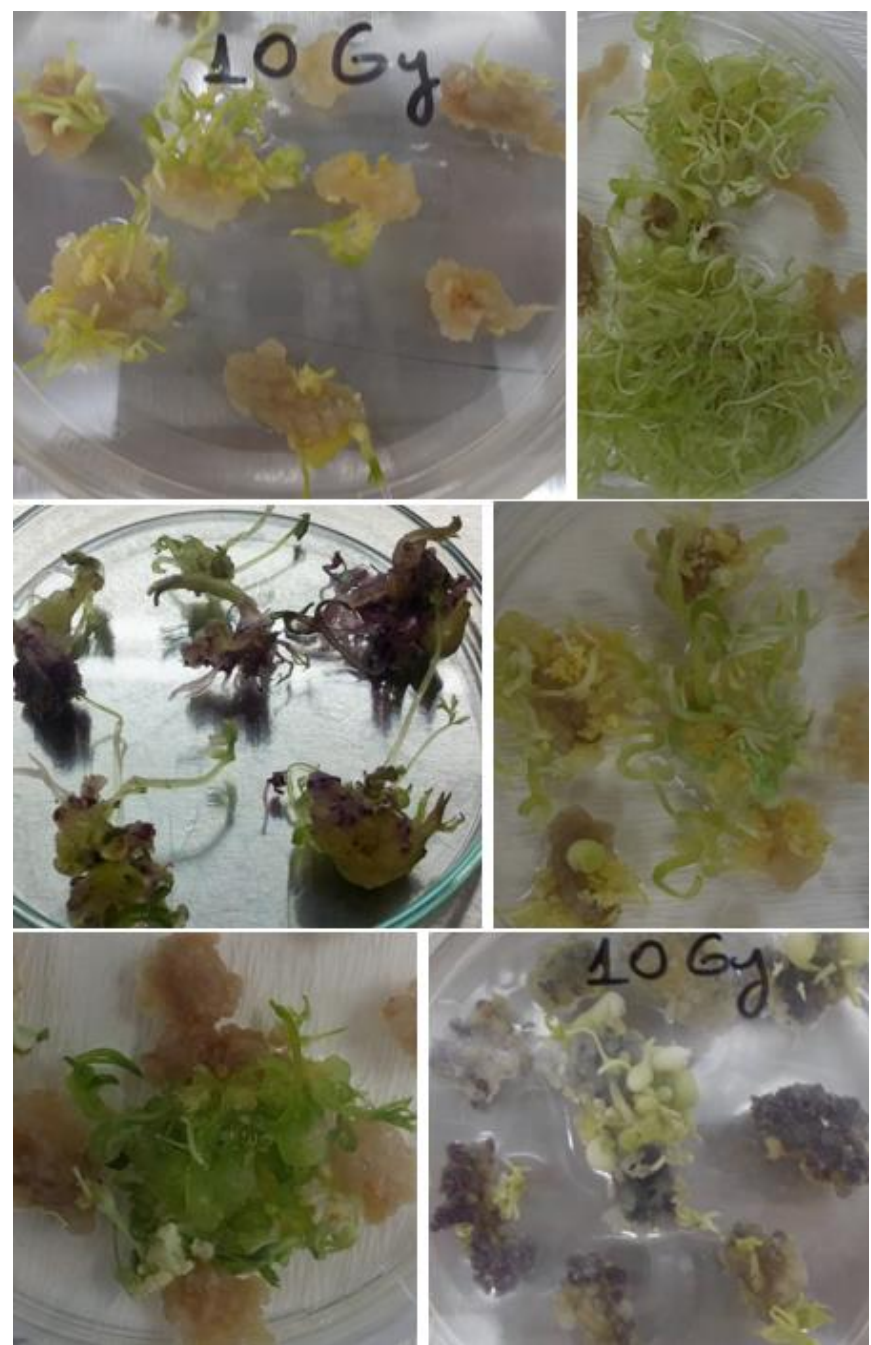

Figure 3. Regenerations from callus tissues belong to orange and purple carrots

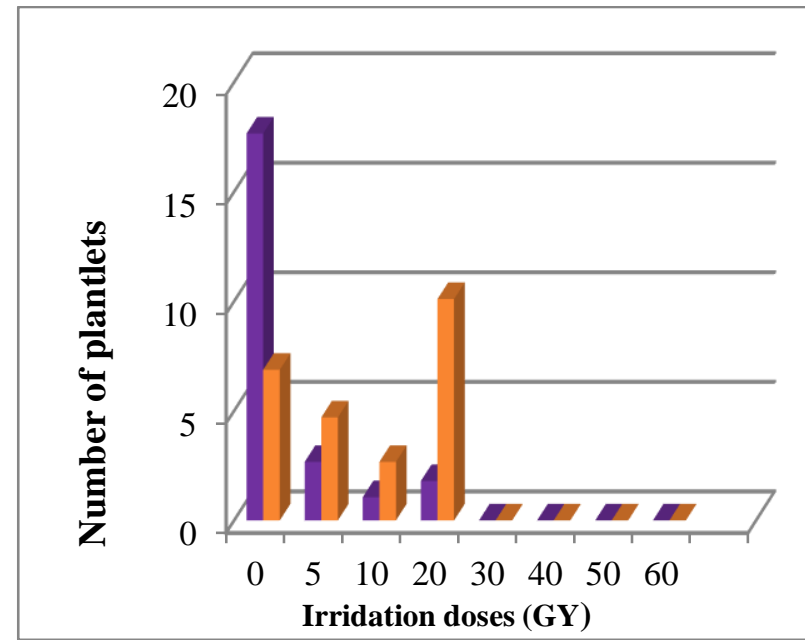

Figure 4. Relative rate of plantlet numbers with different gamma-ray doses 
The effect of irradiation on callus cultures is widely reported in other elite plant species. Venkateshwarlu (2008) studied on lower doses of gamma rays (04 and $05 \mathrm{kRs}$ ) which enhanced the growth of callus in Cucumis melo while higher doses (15 and $20 \mathrm{kRs}$ ) drastically reduced it. According to Chung et al (2006) the gamma irradiation significantly stimulated the shikonin biosyn-thesis in Lithospermum erythrorhizon cell cultures. Moreover, Wi et $\mathrm{a}^{27}$ observed that gamma irradiation remarkably increased the cerium perhydroxide in different tissues of pumpkin. Similarly, El-Beltagi (2011) reported gamma irradiation enhanced the production of antioxidant defense enzymes while reduced ascorbic acid, total soluble protein, amino acids and sugars in callus cultures of Rosmarinus officinalis $L$. The effect of gamma irradiation on callus biomass and biochemical parameters of Stevia rebaudiana Bertoni were reported by Khalil et al (2015) which can be helpful for the establishment of cell suspension culture, and production of bioactive compounds in bioreactors. Calli were transferred to fresh medium and exposed to various gamma irradiations $(5.0,10,15$ and $20 \mathrm{~Gy})$. It has been observed that the increasing doses of gamma rays inhibited callus proliferation (88.61-79.16\%) as compared to control (95.83\%). Researchers like Estramareix et al (1986) LoSchiavo et al (1989), Sung (1976) and Templeton-Somers et al (1981) have studies on carrot mutagenesis and most of the changes were observed at the molecular or cellular levels and not in whole plants. Al-Safadi and Simon (1996), exposed gamma radiation to carrot tissue cultures, germinating seed, and dry seed for their investigation. Irradiation accelerated germination of carrot seed in the M1 generation at low doses ( 0.5 and $1 \mathrm{krad})$, whereas higher doses delayed germination. A high negative correlation was observed between dose and survival of plants after seed irradiation. Plant size and root weight were $20 \%$ to $35 \%$ greater than control plants after seeds, but not tissue cultures, were exposed to low doses of gamma irradiation. Irradiation of germinating seed and tissue cultures yielded more $\mathrm{M} 2$ variation than irradiation of dry seed. Based on the data obtained, $\mathrm{EMD}_{50}$, and $10 \%$ lower and upper values of this dose, may be used as an effective dose in mutation breeding studies for the variety in order to create variability, resistance/tolerance to different biotic or abiotic stress factors.

\section{References}

Ahloowalia, B. S. (1995). In vitro mutagenesis for the improvement of vegetatively propagated plants. In: Induced Mutations and Molecular Techniques for Crop Improvement, Proceedings of IAEA/FAO Symposium. Vienna 19-23 June 1995, pp 531-541.

Ahloowalia, B. S. (1998). In-vitro techniques and mutagenesis for the improvement of vegetatively propagated plants. In: Jain SM, Brar DS \& Ahloowalia BS (eds) Somaclonal Variation and Induced Mutations in Crop Improvement (pp 293-309). Kluwer Academic Publishers, Dordrecht

Ahloowalia B.S., Maluszynski M. (2001). Induced Mutations- A new paradigm in plant breeding, Euphytica 118: 167-173

Al-Safadi, B., Simon, P W., (1996). Gamma irradiation-induced variation in carrots (Daucus carota L.), J. Amer. Soc. Hort. Sci. 121(4): 599-603.

Anonymus., (1977). Manual on Mutation Breeding. International Atomic Energy Agency, Technical Report Series No:119. Vienna, 290p.

Anonymus., (2018). http://european-seed.com/2017/10/world-carrots-one-room/

Chung, B.Y., Lee, Y.B., Baek, M.H., Kim, J.H., Wi, S.G., Kim, J.S., (2006). Effects of low-dose gamma-irradiation on production of shikonin derivatives in callus cultures of Lithospermum erythrorhizon S., Rad. Phys. Chem. 75: 1018-1023

El-Beltagi, H.S., Ahmed, O.K., El-Desouky, W., (2011). Effect of low doses g-irradiation on oxidative stress and secondary metabolites production of rosemary (Rosmarinus officinalis L.) callus culture, Rad. Phys. Chem. 80: 968-976 
Estramareix, C., Rate, P., Boulanger, F., Richaud, F., (1986). Multiple mutations in the transferred regions of the Agrobacterium rhizogenes root-inducing plasmids, Plasmid 15: 245-247

Harborne, J. B., Williams, C. A., (2000). Advances in flavonoid research since 1992, Phytochemistry 55: 481-504

Horvitz, M. A., Simon, P. W., Tanumihardjo, S. A., (2004). Lycopene and beta-carotene are bioavailable from lycopene 'red' carrots in humans, European Journal of Clinical Nutrition 58: 803-811

Khalil, S. A., Ahmad, N., Zamir, R., (2015). Gamma radiation induced variation in growth characteristics and production of bioactive compounds during callogenesis in Stevia rebaudiana (Bert.), New Negatives in Plant Science (1-2): 1-5

LoSchiavo, F., Giovinazzo, G., Terzi, M., (1983). 8-Azaguanine resistant carrot cell mutants and their use as universal hybridizers, Mol. Gen. Genet. 192: 326-329

LoSchiavo, F., Pitto, L., Giuliano, G., Torti, G., Nuti-Ronchi, V., Marazziti, D., Vergara, R., Orselli, S., Terzi, M., (1989). DNA methylation of embryogenic carrot cell cultures and its variations as caused by mutation, differentiation, hormones, and hypomethylating drugs, Theor. Appl. Genet. 77: $325-331$

Maliga, P., (1984). Isolation and characterization of mutants in plant cell cultures, Annual Review of Plant Physiology 35: 519-552

Maluszyuski, M., Ahloowalia, B.S., Sigurbjornsson, B., (1995). Application of in vivo and in vitro mutation techniques for crop improvement, Euphytica 85: 303-315

Montilla, E. C., Arzaba, M. R., Hillebrand, S., Winterhalter, P., (2011). Anthocyanin composition of black carrot (Daucus carota ssp. sativus var. atrorubens Alef.) cultivars Antonina, Beta Sweet, Deep Purple, and Purple Haze. Journal of Agricultural and Food Chemistry 59: 3385-3390

Mou, B., (2011). Mutations in Lettuce Improvement, International Journal of Plant Genomics Vol: 2011, Article ID: 723518, 7 p.

Murashige, T., Skoog F, (1962). A revised medium for rapid growth and bioassay with tobacco tissue cultures, Physiol. Plant, 15: 473- 497

Ross, J. A, Kasum, C. M., (2002). Dietary flavonoids: bioavailability, metabolic effects, and safety, Aпnи Rev Nutr. 22: 19-34

Sagel, Z., Peskircioglu, H., Tutluer, I., Uslu, N., Senay, A., Taner, K.Y., Kunter, B., Sekerci, S., Yalcin, S., (2002). Bitki Islahında Mutasyon ve Doku Kültürü Teknikleri, III: Ulusal Mutasyon Kursu Kurs Notları, TAEK, ANTHAM Nükleer Tarım Radyobiyoloji Bölümü, Ankara (in Turkish)

Schum, A., (2003). Mutation Breeding in Ornamentals: An Efficient Breeding Method. Proj., 21st IS on Classical Molecular Breeding (Ed. G. Forkmann et al.), Acta. Hort. 612: 47-53

Simon, P. W., (1997). Plant pigments for color and nutrition, HortScience 32: 12-13

Sung, Z.R., (1976). Mutagenesis of cultured plant cells, Genetics 84: 51-57

Templeton-Somers, K.M., Sharp, W.R., Pfister, R.M., (1981). Selection of cold resistant cell lines of carrot, Z. Pflanzenphysiol. 103: 139-148 
Waycott, W., Fort, S. B. T., Ryder, E. J., (1995). Inheritance of dwarfing genes in Lactuca sativa L., Journal of Heredity 86(1): 39-44

Wi, S.G., Chung, B.Y., Kim, J.S., Kim, J.H., Baek, M.H., Lee, J. W., Kim, Y.S., (2007). Effects of gamma irradiation on morphological changes and biological responses in plants, Micron 38: 553564

Venkateshwarlu, M., (2008). Effect of gamma rays on different explants of callus treatment of multiple shoots in Cucumis melo cv. Bathasa, J. Environ. Biol. 29: 789-792 